\title{
RASTREAR PERCEPTOS DOS MBYÁ-GUARANI NA ETNOGRAFIA DE CAMINHADA DO MBURUVIXÁ JOSÉ CIRILO PIRES MORINICO: COSMOPOLÍTICA TRANSNACIONAL, PÓS- COLONIAL E HISTORICIDADE ORIGINÁRIA NA REGIÃO PLATINA DO III MILÊNIO
}

JOSÉ OTÁVIO CATAFESTO DE SOUZA ${ }^{1}$

UFRGS

\begin{abstract}
RESUMO: Recuperar a experiência etnográfica de parte da trajetória de vida do Cacique Geral Mbyá José Cirilo - além de ser uma alegria, uma honra e uma oportunidade para sistematizar uma radical transformação pessoal - permite o exercício de um diálogo lateral com as teorias antropológicas pós-coloniais, hermenêuticas e fenomenológicas contemporâneas, na tentativa de arremessar nosso entendendimento ao nível das proposições existenciais (cosmo-ontológicas) $e$ fenomênicas da alteridade radical dos Mbyá-Guarani. Aquém e além dos "conceptos" e do "ser", a proposição filosófica dos Mbyá-Guarani é "estar" (WRIGHT, 2008) ciente a interpretar constantemente os "perceptos" (LÉVI-STRAUSS, 1997), menosprezando a introspecção mental analítica e quantitativa (racionalismo abstrato). Não se trata de um perspectivismo mental ameríndio, mas sim de um perceptivismo corporal Mbyá, centrado no fazer desabrochar novas percepções, desde sentimentos advindos do "coração" (KUSCH, 2000) ou, ao contrário, das partes "telúricas" do corpo. A consciência é dirigida continuamente ao aleatório espontâneo, pois do caótico é preciso extrair compreensão: dos sonhos, dos pensamentos inspirados que chegam à mente e das sensações pouco ordinárias que afetam o corpo, dos fenômenos observados da natureza e do comportamento impensado das crianças. Tudo é objeto de atenção, percebido como signos ou presságios divinos quanto às circunstâncias da vida desperta, dados a serem interpretados em sua imediaticidade, a fim de que se chegue ao diagnóstico sobre a situação atual e à decisão certa a tomar em cada uma das encruzilhadas que perfazem o caminhar da vida. O Mburuvixá Cirilo é protagonista de uma legítima cosmopolítica transnacional em sua busca pelo "Belo Caminho da Tradição", pois sua trajetória começou criança, nos confins das florestas das Misiones (Para Miri), tornando-se jovem liderança em comunidades na Argentina junto à dor pela morte prematura de seu filho primogênito, quando foi se esconder no fundo da floresta para se concentrar "espiritualmente", conversar com o Deus, ao ponto dele receber um canto mágico para lhe tranquilizar o coração e lhe tornar um Xondaro Marangatu ("guardião
\end{abstract}

\footnotetext{
${ }^{1}$ Etnoarqueólogo, pesquisador e professor motivado pelo desvelamento das alteridades originárias e pela produção de diálogos laterais com agentes e coletividades ameríndias e quilombolas rurais na amplitude do Mercosul. Segue o lema formulado por Airton Krenak: "Fazer local, pensar global". Crítico contumaz do produtivismo acadêmico e da dominação do utlilitarismo nas Ciências Sociais. Possui formação acadêmica na UFRGS: licenciatura em história (1982), mestrado (987) e doutorado (1999) em antropologa social. Atua como professor adjunto na mesma universdade, onde coordena o LAE - Laboratório de Arqueologa e Etnologia que desenvolve projetos de pesquisa sobre Terrtorialidade Mbyá-Guarani, Etnoarqueologia Ameríndia e Quilombola e Avaliação dos Impactos de Projetos de Desenvolvimento sobre coletivos rurais. Prioriza atvidades de ensino e de extensão subvalorizados pelos critérios neoliberias vigentes no meio científico brasileiro, trabalhando com disciplinas como Antropologia Fundamentos, Desafios Contemporâneos, Leituras Etnográficas, Métodos Qualitativos, Cultura e Sociedade no Brasil, Arqueologia, Etnoarqueologia. E-mail: catafestodesouza@gmail.com .
} 
da Tradição”). Por indicação de Nhanderú, depois veio com a família na direção de Para Guaçu, litoral do Brasil, e tornou-se Mburuvixá Tenondé, liderança política originária que representa o respeito ao Tekó Porã (Belo Viver), preservando a alegria e o respeito à tradição dos mais velhos, velhas e das lideranças espirituais (Karai Kuery e Kunhã-Karai Kuery), verdadeiro articulador étnico, agente intercultural e mediador capaz de "sensibilizar o coração dos brancos" (mexer em nossos perceptos) e adaptar as politicas indigenistas desde "costuras" interinstitucionais, que se efetivam em ações políticas concretas afinadas ao holismo do Mbyá Rekó. E, ainda, mantendo a índole aguerrida dos primeiros Guarani, no sentido literal do termo, participando de processos de autodemarcação da Terra Indígena do Campo Molhado em 1994 e na recente retomada da aldeia Tekoa Ka'a Guy Porã nas matas dentro da área da extinta FEPAGRO, em Maquiné, RS.

PALAVRAS-CHAVE: Cosmopolítica; José Cirilo Morinico; Mbyá Rekó.

ABSTRACT: To recover the enographic experience of part of Mbyá José Cirilo's life trajectory is not only a joy, an honour, and a great opportunity to systematize a radical personal transformation, but also allows the establishment of a lateral dialogue with post-colonial, anthropological theories, as well as hermeneutics and contemporary phenomenology, in the attempt to understand the existencial propositions (cosmo-ontology) of the Mbyá-Guarani's radical alterity. Beneath and beyond the "concepts" and the "to be", the Mbya's philosophical proposition is "being" aware to interpretate constantly the "percepts" (LÉVI-STRAUSS, 1997), undermining the mental introspection, both analytical and quantitative (abstract rationalism). It is not about a mental, Amerindian perspectivism, but a corporal, Mbyá perspectivism, centered in making new perspections bloom, from feelings felt in the "heart" (KUSCH, 2000), or even in the "telluric" parts of the body. The consciousness is driven continuously towards the spontaneous, the random, since, from the chaotic, one must extract comprehension: of dreams, of inspired thoughts that come to mind, of uncanny sensations that affect the body, of nature's observed phenomena, of the children's reckless behavior. Everything is an object of attention, perceibed as a sign or divine portent, facts to be interpreted in their immediacy, in order to achieve a diagnosis on the current situation, and the right decision to take once one is facing the many crossroads that exisit in life. The Mburuvixá Cirilo is the protagonist of a legit transnational cosmopolitics, in his search for the "Beautiful way of tradition", as his path has begun as a child, in the confines of the florests in Misiones (Para Miri), where he became a young leadership in communities in Argentina, hiding in the woods to cope with the death of his first son, to connect spiritually, to talk to God. And so it was, to the point that he received a magical chant from Nhanderú, for his heart to be peaceful, for him to become a Xondaro Marangatu ("guardião da Tradição"). Afterwards, he came with his family to Para Guaçu, in the Brazilian coast, and became Mburuvixá Tenondé, the original political leadership that represents the most elevated respect to Tekó Porã (Belo Viver), preserving joy and respecting the elder's and the spiritual leader's tradition (Karai Kuery and Kunhã-Karai Kuery). A true ethnic articulator, an intercultural agent and mediator, capable to "touch the heart of the whites", to adapt indigenous policies, turning them into real, concrete political actions, always tuned with Mbyá Rekó holism. And all that still maintaining the courageous, wary character of the first Guarani, participating in self-demarking land process, such as the Terra Indigena do Campo Molhado, in 1994, and the recent retaking of Tekoa Ka'a Guy in Maquiné, RS.

KEYWORDS: Cosmopolitics; José Cirilo Morinico; Mbyá Rekó. 
Se Existo, Logos Canto!

Provérbio Gaudério Anônimo

Devemos seguir a Ayvu Porã (Bela Sabedoria), Palavras Vivas afinadas com a Natureza Nhanderú envia pensamentos inspirados à retomada de nossos territórios originários Mburuvixá José Cirilo Morinico

A redução fenomenológica é fazer as coisas retornarem a elas mesmas. Edmund Husserl (1950)

\section{Introdução}

Recebi com grande honra o convite (e a positiva provocação intelectual) para refletir sobre a conjuntura contemporânea do indigenismo Sulamericano e da teoria etnológica desde a trajetória de vida do Mburuvixá José Pires Morinico. Honra porque, em primeiro, Cirilo é mais do que um parceiro, aliado e amigo; é também um grande mestre, verdadeiro estudioso do Mbyá Rekó, filósofo e antropólogo originário dedicado também ao entendimento dos mundo do juruá (branco). A ele devo grande aprendizado, não apenas sobre os Mbyá, mas, principalmente, como mestre da arte do Bem Viver neste nosso Mundo Decaído. É um privilégio compartilhar a existência com ele e com outros tantos parceiros neste Teko Axy. Como bem retrata a frase de homenagem de alguns alunos e alunas pirografada em uma pequena cuia que recebi de presente recentemente: Tantos Siglos, Tantos Mundos, Tantos Espacios y Coincidimos!

Este texto é o produto de uma série de paralelismos e de convergências que se fazem entre trajetórias de vida, entre a mobilização étnica internacional dos Mbyá e a dedicação dispersa e quase voluntária de poucos parceiros "brancos" (abnegados), aproveitando as brechas e as contradições das instituições oficiais, públicas e privadas, lutando contra os vícios do patriarcalismo, do patrimonialismo, do racismo e do etnocentrismo enraizados passivamente na mentalidade das elites políticas locais que mantêm a dogmática hegemônica do sistema capitalista mundial. Convergências entre os avanços consolidados com a vigência da Constituição Federal Brasileira (CF) em 1988 e a chegada do Mburuvixá José Cirilo e de sua família no Brasil mais ou menos nessa 
mesma época. Convergências entre a execução de ações institucionais em prol de comunidades indígenas e a realização de pesquisas etnológicas entre originários, como ocorreu na experiência de Daniele de Menezes Pires como estagiária do CEPI (Conselho Estadual dos Povos Indígenas, Governo do Estado do RS), aproveitando as tarefas administrativas em contato direto com os Guarani para recolher dados empíricos que fundamentam sua dissertação de mestrado (PIRES, 2007) sobre os Mbyá. Dados e linhas de argumentação deste trabalho são aqui retomados, principalmente no momento em que se desenvolve uma descrição biográfica de José Cirilo.

A maior das convergências é bem pontual e foi descoberta depois de iniciado este texto, quando um primeiro esboço da escritura foi apresentado oralmente em leitura feita ao Cacique Cirilo em novembro de 2016, a fim de ter sua avaliação quanto ao teor da narrativa e à minha linha de argumentação. Foi um diálogo frutífero por revelar outros aspectos da vida do Cacique Cirilo integrados ao texto, mas, principalmente, por uma informação com impacto direto no processo de escrita, até então supostamente sob minha exclusiva autoria. Em todos os momentos mais críticos de sua vida - como veremos adiante -, José Cirilo adotou a estratégia de se dirigir ao mato ou à floresta mais íntegros existentes em torno à sua aldeia, numa expedição solitária de procura pelo contato direto com Nhanderú Tenondé, tanto para pedir força, apoio e orientação spiritual, quanto para resolver dilemas existenciais. Pois bem, José Cirilo informou que, há mais ou menos um ano, efetuou uma dessas expedições especialmente planejada para lançar à Nhanderú a seguinte questão: "Quem irá escrever a trajetória de minha vida?". Confesso que imaginar ser eu um instrumento das forças cósmicas em paralelo às expectativas dos originários Mbyá deixou-me com um certo orgulho, mas ainda mais tranquilo para conseguir fazer aflorar as palavras inspiradas vindas aquém e além deste meu eu autoral, na intensidade e respeito que a sabedoria dos Mbyá merece.

Entretanto, não há apenas convergências a destacar neste texto, mas também a radicalização de algumas dificuldades. Depois de décadas, José Cirilo consolidou permanência e ajudou na maior visibilidade da alteridade étnica Mbyá no Brasil, obtendo maior reconhecimento das instituições públicas, maior número de apoiadores e alguns poucos, mas 
significativos, resultados concretos. Todos reconhecem que os Mbyá possuem direitos originários sobre o território e que eles precisam de terras demarcadas em locais onde as condições ambientais sejam adequadas à sua reprodução física e cultural; e, no entanto, é crescente a falta de espaços naturais ainda não degradados onde as novas gerações de Mbyá-Guarani possam continuar reproduzindo seu sistema cosmoecológico tradicional. As poucas áreas com matas mais preservadas no Rio Grande do Sul foram mapeadas e reivindicadas pelos Mbyá desde 1996 (processo de que José Cirilo participou). Depois de mais de duas décadas, quase todas essas áreas se mantêm como propriedades privadas e, enquanto a burocracia brasileira nada faz em prol de seu destino ao usufruto dos Guarani, elas continuam a ser degradadas em nome do progresso nacional e da ordem privada, substituídas por lavouras, pastagens, lagos hidrelétricos e cidades, sempre priorizando ganhos particulares, e não coletivos.

A morosidade burocrática não é aceita de maneira passiva pelos Mbyá-Guarani e, aqui, é necessário reconhecer a complementaridade entre as diferentes estratégias de barganha e luta utilizadas e experimentadas por Cirilo desde que chegou no Brasil. Junto ao querer "ganhar o coração dos brancos" está a permanência de uma personalidade aguerrida e forte, disposta a lutar como sempre estiveram os Guarani enquanto povo guerreiro e conquistador desde antes de Critóvão Colombo. José Cirilo participou ativamente do processo de autodemarcação da Terra Indígena do Campo Molhado (Barra do Ouro) em 1994, enfrentando os capangas e empregados dos posseiros que se intitulavam fazendeiros. Da mesma forma como José Cirilo, seguindo as inspirações de Nhanderú, está mobilizado e junto aos Mbyá desde os primeiros acampamentos (janeiro de 2017) de retomada de terras com matas nativas (Yvyrupa), anteriormente transformadas em área de "propriedade" da extinta FEPAGRO. José Cirilo continua na luta pela consolidação dos direitos originários de muitos Kuery Mbyá.

$\mathrm{Na}$ atual conjuntura política brasileira, em que todos os processos demarcatórios foram suspensos, em que se votam no Congresso Nacional e no Senado uma série de Projetos de Emenda Constitucional (como a PEC 215) e Projetos de Lei (PL) contrários aos avanços formais de 1988, José Cirilo se mantém perseverante frente ao crescente questionamento do 
pleno reconhecimento de direitos diferenciados indígenas e tranquilo frente às iniciativas conservadoras que refreiam as medidas compensatórias criadas para mitigar minimamente os prejuízos históricos acumulados sobre os povos originários no país. Tranquilo mesmo sabendo dos ataques aos acampamentos e dos homicídios frequentes dos Kaiová Guarani por pistoleiros e capangas no Mato Grosso do Sul. A sabedoria Mbyá não se abala com os adventos meramente políticos ou ameaças de morte: eles se mantêm mais focados nas emanações cosmoecológicas que, para eles, definem as coisas do mundo ordinário, incluindo os acontecimentos políticos. Atualizando um dizer de Egon Schaden (1974) sobre os Guarani de São Paulo de meados do Século $\mathrm{XX}$, os Mbyá continuam sendo filósofos, mesmo que agora já sejam raras as florestas; eles continuam filosofando na beira das estradas, nas periferias urbanas e nas audiências públicas, inclusive usando o português. Falo em filosofia Mbyá não no sentido do pensamento que se projeta sempre para fora em busca de "suas" causas exteriores (aos moldes do Europeu), mas sim enquanto "pensamento seminal" (KUSCH, 2000) que se funda no coração, pois eles nos ensinam que, antes, advém o corpo enquanto suporte de percepções, e buscam sempre as emanações sutis de onde advém sua sabedoria e a volatilidade poética das palavras inspiradas.

A receptividade cordial dos Mbyá quanto ao desenvolvimento de meu trabalho etnográfico entre eles compromete-me repercutir as Belas Palavras proferidas por Sábias e Sábios Guarani, traduzidas por José Cirilo e outros Guarani, inclusive quando eles argumentam que são escolhidos por Nhanderú Vuçu para evitar uma nova destruição geral da Calota Terrestre. O sistema de vida dos Mbyá-Guarani - o Teko Porã - é a resposta mais harmônica possível a servir como exemplo a ser reproduzido ao advento de um novo tipo de Humanidade que ainda está por surgir. Ou, talvez, seja melhor dizer: ressurgir das cinzas, renascer depois de sucessivas campanhas de genocídio, etnocídio e velamento oficial promovidas à construção dos países que se implantaram e dividiram seus territórios tradicionais, colocando-os à margem tal qual "estrangeiros em suas próprias terras" (MELIÁ, 1988). A formulação de princípios como "Mata Livre", "Territorialidade Livre", "Saúde enquanto Alegria" e "Sustentabilidade enquanto Celebração Coletiva Espiritual" são 
exemplos de tentativas institucionais de adequação de projetos políticos e de ações administrativas aos princípios culturais específicos dos Mbyá. Nisso tudo houve, e há, a intervenção intelectual, ritual e espiritual de José Cirilo, principalmente no Rio Grande do Sul.

Retornado ao tema dos paralelismos, a convergência mais surpreendente a explorar é entre as "proposições cosmo-ontológicas", conforme as conclusões próprias, desdobradas dos dados etnográficos entre os Mbyá, com a dimensão teórica, paradigmática e conceitual de certas escolas do pensamento epistemológico e antropológico atuais principalmente daquelas englobadas pelo rótulo de paradigma da desordem (OLIVEIRA, 2004). Antropólogos, hermeneutas e fenomenólogos formularam interpretações teóricas e metodológicas muito similares às interpretações obtidas pela análise indutiva dos dados etnográficos coletados sobre a dimensão traduzida pela noção de "espiritualidade" veiculada pelos Mbyá, conforme foram se revelando no acompanhar da trajetória de vida de José Cirilo e de outros interlocutores Guarani circulando pelo Brasil e pela Argentina. Tomamos por referência inicial as posições e divergências de interpretação (considerando que explicar e compreender são tomadas, aqui, como variantes do interpretar), colocadas dentro da matriz disciplinar da antropologia, em geral, e da etnologia ameríndia Sulamericana e brasileira, em particular (VIVEIROS DE CASTRO, 2002; DESCOLA, 1992; FAUSTO, 2005).

Intenta-se aqui, como propõe Roy Wagner (2010), gerar alguma reversão antropológica levando a sério a sabedoria Mbyá, tomada através da vida de José Cirilo, complementando o estudo dos efeitos lógicos das "palavras" Mbyá na busca por reconhecer a amplitude corporal, perceptiva e afetiva aquém e além das formas lógicas e abstratas mais evidentemente implicadas. Para tanto, as "palavras" devem ser tomadas sempre em referência aos seus contextos fenomênicos de manifestação. A experiência vivencial direta com os Mbyá, seja na intimidade dos fogões familiares (tata ypy rupa), seja em viagens ou em reuniões institucionais, é um processo marcado por sucessivos momentos de desconforto emocional, em que surgem sentimentos, sensações e pensamentos que a consciência não controla. E a dica dos Mbyá é apostar na dimensão divina desse aparente descontrole mental, pois nele está contida a sabedoria perfeitamente adequada às circunstâncias atuais, ao momento em que se 
encontra a caminhada de nossa existência.

O pensamento dos Mbyá procura sua própria anulação, atento à inconstância do que está dentro e fora dele, duvidando da dimensão secular e da lógica materialista, ambas civilizadas, que os cercam. Algo como uma certa errância tipificada por Lévi-Strauss enquanto característica do Pensamento Selvagem, celebrando signos e imagens oníricas mais ligados aos perceptos do que aos símbolos ou aos "conceptos". A etnologia indígena é profícua no debate sobre os "Guarani de papel" e reproduz certos desvios interpretativos consolidados pela hermenêutica jesuítica e crista - não apenas por causa da íntima atuação missioneira durante o Período Colonial, mas, principalmente, porque grandes estudiosos contemporâneos são religiosos, como exemplificam os nomes de León Cadogan, Bartomeu Meliá e Graciela Chamorro. E ainda há o hibridismo, produzido contemporaneamente pela ação indigenista de membros de igrejas libertárias da América Latina, dando origem ao aparecimento de um certo sincretismo, como em: a) a busca pela Terrasem-Mal enquanto o mesmo que o Paraíso Cristão pós-morte; b) o reconhecimento de Sepé Tiaraju enquanto Herói Brasileiro e uma versão oralizada dele enquanto um messias (Jesus Cristo) Guarani.

Conviver com José Cirilo e com os demais Mbyá-Guarani dá a este texto uma grande vantagem, pois ultrapassa o conhecimento dos papéis (estudos publicados) que versam sobre eles, em contraponto com a minha experiência corporal, perceptiva, fenonomênica, além de me conter em reproduzir o que já escreveram sobre eles. De igual forma, a posição acadêmica engajada dá liberdade ao estudo por não depender de subsídios produtivistas ou intervenções religiosas, aprofundando a crítica frente a certas alianças assistencialistas que ainda submetem certas lideranças Mbyá à questão mais geral da "luta" de classes, popular, rural e social dos desfavorecidos e discriminados.

É necessário ultrapassar a questão da perspectiva e do perspectivismo lógico abstrato, buscando analiticamente os efeitos corporais, e mesmo perceptivos, induzidos na formação dos órgãos do sentido e da personalidade Mbyá de adultos desde a infância, tanto pelo convívio íntimo com a ecologia das florestas, das matas e dos cursos de água, quanto pelo ambiente de convívio familiar e social que acontece predominantemente em espaço aberto - no oká ("patio"), fora de 
construções e regado com o cheiro da fumaça de diferentes tipos de madeira e do tabaco, tal qual o papel do incenso à concentração espiritual em muitas religiões em todo o mundo. É preciso incluir a importância da comensalidade que produz a consubstancialização dos corpos pela dieta ou pelo jejum compartilhados. Viver e comer juntos tornam as pessoas aparentadas entre e para os Mbyá. Há ainda a força dos rituais para influir na modelagem dos filtros perceptivos, efeitos do sacudir cadenciado dos corpos em passos conjuntos e dos taquapy batidos pelas mulheres socando a superfície do solo, embalados pelo ritmo do coral de vozes e do som de instrumentos tradicionais. As Belas Palavras são apenas a cereja do bolo, pois mesmo o solo treme com a dança de velhos, adultos, jovens e crianças em seus rituais tradicionais. Impossível não acelerar o coração e não sentir cargas de adrenalina a provocar alterações da consciência, compartilhadas na comoção de sentimentos coletivos.

Trata-se de reconhecer que a ambiência ecológica e ritual cria inegáveis interferências sobre os filtros perceptivos (E. HALL, 2003) dos envolvidos, alterados na efusão emocional provocada pelo receio e pela admiração dos seres misteriosos das florestas, do subsolo e das águas e pela participação constante em rituais. Talvez seja por isso que muitos do público de brancos chorem quando escutam e assistem a apresentações dos Grupos de Canto e Dança de Jovens e Crianças MbyáGuarani. José Cirilo diz que isso se dá pelo fato de que as vozes das crianças são emanações vindas diretamente dos deuses, para tocar nossos corações! Os Mbyá são mestres na arte de produzir alterações em nossos níveis de consciência. Basta apenas se permitir conviver um pouco com eles.

Levar a sério a proposta "espiritual" dos Mbyá é sair do nível confortável do lógico para suspendê-lo, para entender como os MbyáGuarani procuram e estão atentos às alterações que atingem a percepção externa e também interna ao corpo, incluindo as manifestações imagéticas, oníricas e simbólicas produzidas supostamente (para nós, cientistas) pela mente individual. E, ainda mais, sua cosmoecologia concebe possível manipular a materialidade e as propriedades substanciais dos corpos, seja através da dieta, seja pela participação em procedimentos rituais, ou pela introdução de objetos mágicos no corpo de pessoa atingida por feitiçaria. Levar a sério os Mbyá é pensar possível 
conversar com deuses e com os espíritos guardiões dos entes naturais (animais, vegetais, minerais), assim como é preciso respeitar os espectros de mortos que vivem nas matas e que rondam as casas durante a noite. É necessário suspender nossos preceitos lógicos mais arraigados para aceitar possível que a consciência suba em direção ao céu e converse com o Grande Pai, atravessando imensas distâncias pelo ar ou sob as águas, tudo em lapsos de segundo.

É possível aceitar cientificamente o pressuposto cosmo-ontológico mais marcante dos Mbyá-Guarani: o Aguyje Véte? É muito impactante para qualquer pesquisador quando se entende o sentido dessa expressão e quando se observa ela ser sempre manifesta enquanto protocolo de saudação para todo e qualquer visitante - inclusive brancos - ao chegar numa comunidade. A saudação dos visitantes dos Mbyá é algo como: "Desejo que todos nós alcancemos a Imortalidade!". Os Mbyá sabem que tal condição de imortalidade, alcançada pelos Nhanderú Miri (pessoas divinizadas), é uma possibilidade, embora reconheçam ser muito difícil e remota, pela dedicação espiritual implicada. Exige uma grande ascese, através da regulação rigorosamente vegetal da dieta (exceto o mel), e concentração espiritual através de constantes rituais de reza, de canto e de dança, de abstinência sexual, tornando possível a homens e mulheres dedicados a tal propósito alcançar essa condição de imortalidade fazendo o corpo leve e energizado ao ponto de flutuar. Em contrapartida, podemos aceitar cientificamente que a condição de tupichuá possa tomar conta completamente do corpo do caçador que come a carne crua da caça sozinho na floresta, literalmente transformando o corpo e o espírito dele no de um jaguar eté (onça), metamorfoseado o ser humano na espécie de animal que tem esse tipo de comportamento?

Se, para a antropologia e para a ciência, tais possibilidades são apenas fantasias, devo admitir que fui e sou atingido diretamente no coração sempre que interajo com os Mbyá. Minha experiência etnográfica, perceptiva e existencial junto do Mburuvixá Tenondé José Cirilo e demais Mbyá exige a procura de algum referencial conceitual que respeite e reflita sobre a sua seriedade no trato desses temas, pelo profundo respeito manifesto em seus rituais e na expressão de sentido, ao mesmo tempo poético e literal, de suas Belas Palavras. Vale muito a empreitada para vasculhar os contextos fenomênicos de formulação e analisar seus 
efeitos sobre os corpos e sobre a percepção dos sentidos, mesmo que eu ainda não tenha a dedicação espiritual necessária para vislumbrar algo além da condição decaída que todos nós mortais compartilhamos. Arrisco imaginar controladamente tais temas em paralelo à trajetória de vida de José Cirilo, mesmo que eu não tenha o corpo e a mente de um Guarani, mesmo que não faça parte do grupo de eleitos por Nhanderú para salvar o mundo; pelo contrário, faço parte da sociedade que veio a se criar nos campos surgidos pela devastação das florestas por gafanhotos originários, segundo descrevem os mitos Mbyá de criação desta Segunda Terra (Yvy Piau).

Habitus e Perceptos Florestais: reproduzindo a itinerância de Nhanderú

Dimensionar analiticamente a importância antropológica da trajetória de José Cirilo exige partir da desconstrução de certas ideiasvalor (DUMONT, 1997) consolidadas em nossa tradição mental. Quantos leitores deste texto, além dos Mbyá, possuem a experiência incorporada de convívio íntimo com o ambiente florestal? Caçadores, mateiros, campistas, expedicionistas possuem tal intimidade, mas poucos fizeram sua primeira infância tendo a floresta como quintal de casa. Acredito que a maior parte dos que lêem estas linhas foram domesticados (no sentido dado por Lévi-Strauss em $O$ Pensamento Selvagem) dentro de quatro paredes ou dentro de pátios murados. Ângulos retos a condicionar nosso campo perceptivo, na conformação dos móveis e utensílios, nas folhas e linhas do papel onde fazemos nosso treino mental e nossas elaborações intelectuais.

Tal problemática é trazida por Ingold (2012) quando propõe substituir a ideia de objeto pelo conceito de "coisa". A ideia de objeto científico é produzida sobre uma base ou um campo perceptivo, em que nossos filtros de percepção estão condicionados pela manipulação de objetos artificiais independentes, produzidos pela fabricação humana desde materiais extraídos do mundo. Os materiais se transformam em objetos, e sua composição é reduzida à condição de pura matéria. Brinquedos, utensílios, os ângulos retos nas esquinas e o alinhamento do traçados das ruas, a verticalidade reta das construções e o esquadro das 
aberturas, tudo a nos condicionar a pensar o mundo enquanto composto de "caixinhas" (diz Cirilo), ainda mais que nossos documentos são separados em gavetas, o que se acresce na modulação de nossos filtros perceptivos. Rénè Descartes transformou isso no método do plano cartesiano, composto de abscissas e coordenadas perpendiculares.

Por outro lado, a noção de coisa é proposta como alternativa para ultrapassar os níveis perceptivos típicos do ambiente urbano, para resgatar a consideração perceptiva de que todas as entidades do mundo estão conectadas e de que o limite entre elas sempre é um gradiente híbrido. Tudo depende do foco e do nível de aproximação - nada de limites rígidos. Os insetos e as plantas que parasitam uma árvore fazem ou não parte dela, pergunta Ingold. As fezes intestinas fazem parte do animal? O sedimento degradado da rocha (terra, areia) faz parte dela? No mundo da vida (o conceito é proposto pelo autor em substituição ao de agência), não existem apenas materiais, mas sim materialidades, formas de manifestação híbrida daquilo que transformamos em matéria-prima dos objetos produzidos por nossa tecnologia humana.

O corpo é a primeira e principal "coisa" de nossa existência, nosso "primeiro instrumento" técnico, já nos ensinou de forma seminal Marcel Mauss. A base corporal não é resultado apenas de genética: é muito o produto das formas como as coisas são feitas, de como cada coletividade "fabrica" (VIVEIROS DE CASTRO, 1979) os corpos de seus participantes. Trata-se de buscar o habitus enquanto "imitação prestigiosa" (MAUSS, 1950), enquanto "disposições corporais duráveis" (BOURDIEU, 1974), principalmente quando o foco de análise são os gradientes híbridos que conectam os corpos e as percepções dos Mbyá com os componentes da ecologia que os circundam e da cosmologia que projeta sua consciência a caminhar pelo mundo em busca de seu tipo radical de redenção ontológica.

Os Mbyá têm a morfologia de seus corpos adaptada às condições florestais e ao deslocamento por grandes distâncias em terrenos irregulares: os corpos são geralmente esquálidos e esguios; as palma dos pés têm pele grossa, treinada, desde a infância, a caminhar descalça; a pele do corpo tem a cor de um bronze escuro, reforçado a cada dia pela ação de sol queimando seus corpos nas clareiras, roças e pátios de suas casas. Suas articulações são flexíveis, principalmente as pernas, pela 
prática de se acocorar diariamente junto aos seus fogões familiares. A praxis, as técnicas corporais originárias dos Mbyá estão, hoje, um pouco mudadas (falta de matos), mas é necessário recordar que estamos tratando da época de infância de José Cirilo e, para ele, isso foi - e ainda é - muito válido.

É experiência marcante acompanhar José Cirilo e outros Mbyá em suas expedições nas matas. Seu comportamento se transforma numa atenção exacerbada ao olhar, ouvir e captar aromas simultaneamente. Eles parecem fazer sempre o exercício de voltar a atenção à visão periférica (aura imprecisa), inclinando a cabeça para acertar o ângulo de entrada de cada som específico no pavilhão auricular, separando-o do seu eco florestal. Eles vão dando passos absortos em cada detalhe do solo, dos ramos e das plantas pelas quais passam. Interessa, portanto, saber como se regulam os filtros perceptivos das crianças originárias que se criam no ambiente florestal, ainda mais quando elas realizam constantes expedições sozinhas mata a dentro. Esse é o caso ocorrido com José Cirilo, pois até os oito anos ele viveu junto de sua família, marcado pelo abandono do pai logo aos dois anos de idade. Ele teve a orientação parcial do irmão mais velho na primeira socialização, mas não teve aquele tipo de "iniciação florestal" mais intensa, quando a criança acompanha a rotina paterna. As dificuldades de sua vida infantil foram enfrentadas de uma forma deveras divergente, mesmo para o costume Mbyá. Ele aprendeu, desde cedo, a procurar respostas às dificuldades e às contingências da vida em caminhadas sozinho na Floresta, para conversar pessoalmente, sem intermediação, com Nhanderú.

José Cirilo nasceu na Sexta-Feira Santa do dia 12 de abril de 1974 na Aldeia de Salto Tavaí (Província de Misiones, norte da Argentina). Sua primeira infância foi completamente vivida nessa aldeia tradicional, junto de uma floresta preservada e com uma bela cachoeira. Proponho ao leitor imaginar o que é ser uma criança Guarani dentro de sua aldeia tradicional, vivendo cotidianamente com a mata e quase sem contato com o mundo dos brancos. Assim foi toda a primeira infância de José Cirilo, sem as limitações perceptivas imputadas às nossas crianças treinadas para procurar espaço de intimidade dentro de quatro paredes (dormitórios individuais, banheiros). Até hoje, quando as famílias Mbyá ficam recolhidas ao interior de suas casas tradicionais (óga) — apenas em dias 
de chuva intensa, frio ou às noites - e que não possuem divisões internas, a fumaça do fogão de chão ultrapassa as fibras vegetais das paredes e do teto e se lança para fora. Os ruídos da noite e da mata próxima ultrapassam a materialidade e a espessura das paredes às vezes, fazendo eco às Belas Palavras proferidas pelos mais velhos (Karai Tujá) a estimular a imaginação mítica e a conduzir o sono das crianças em contanto com os ruídos da noite.

Além disso, a aldeia de infância de José Cirilo tinha Opy (Casa de Cerimônias de canto, dança e reza), e ele foi, desde então, um frequentador assíduo: aprendeu a celebrar os rituais tradicionais e a respeitar a Sabedoria expressa pela Ayvu Rapitã e pela Nhe'e Porã (Belas Palavras) dos diferentes tipos de Karai e Kunhã-Karai com quem já conviveu. A intensidade emocional coletiva ("espiritual", segundo Cirilo) gerada dentro da Opytornou-se um dos pilares de sua vida, em paralelo à sua procura individual pela orientação divina, sozinho, nos "templos" das florestas.

Para lançarmos uma aproximação aos perceptos florestais originários, tão formadores e centrais na trajetória de vida de José Cirilo e tão importantes aos Mbyá, é necessário, primeiro, neutralizar - ou, ao menos, dar ciência sobre - os nossos perceptos objetivantes (produtores de objetos) e que se constituem também nos fundamentos da ciência moderna. Há que se reconhecer também sequelas geradas por nosso urbanocentrismo e sobre as modulações perceptivas quando as pessoas vivem a vida continuamente aprisionada em espaços fechados, dentro e em torno de obras arquitetônicas e de grande engenharia. Para fazer o exercício de imaginação metodologicamente controlada do que seja a "cosmovisão" mbyá (preferimos corporalidade, habitus e percepção), é mister neutralizar nossas "cabeças quadradas" José Cirilo divertiu-se e riu muito dessa expressão, concordando com seu uso para entender os juruá kuery).

Nosso ritmo urbano de tempo e espaço é radicalmente diferente ao dos Mbyá-Guarani, que é predominantemente itinerante. O paleoetnólogo francês André Leroi-Gourhan (1987) fez esta distinção importante quanto aos tipos de ritmos de ocupação espaço-temporal aplicados pela humanidade ao longo dos tempos: o "radial", que estabelece a existência de um centro de onde partem e aonde voltam as 
pessoas nas lidas diárias, e o "itinerante", representado pela sucessão entre um traço e um ponto (percurso-acampamento). O Jeguatá Tape Porã é indicativo de que o valor da mobilidade e da itinerância são centrais na cosmoecologia Mbyá. A vinda de José Cirilo e sua família para outro país e para outra região do continente sul-americano também exemplifica isso. Cosmo-ontologia radicalmente distinta da eurocentrada, esta última fixada em fundamentos e marcos concretos cravados no solo, nos fundamentos permanentes do patrimônio e da apropiração privatista da superfície e das coisas terrestres, no ouro supostamente eterno guardado em cofres enterrados.

É ainda mister ter ciência de outras limitações colocadas por nossa tradição greco-romana-judaico-cristã, advinda da Europa Ocidental, para entender o habitus florestal, trazendo reflexões sintetizadas no clássico estudo histórico e geográfico de Frederick Turner (1990) O Espírito Ocidental Contra a Natureza. Esse autor recorda que a tradição judaicocristã surgiu nas condições desérticas do Oriente Médio, gerando religiões típicas do ambiente árido, onde a visão alcança o horizonte distante. Por isso, desde a chegada dos primeiros conquistadores europeus depois de 1492, as florestas tropicais americanas foram associadas ao reino do demônio, da luxúria envolvente, de perdição, das trevas e de desordem selvagem. Segundo Michael Taussig (1993), tratando do caso do Putumayo (Colômbia), os europeus deixaram registros diversos e abundantes, manifestando sentimentos negativos sobre as florestas e matas, algo que o autor designou como um verdadeiro "terror da selva".

Assim, sugere-se ao leitor lançar sua imaginação controlada à grande diferença existente entre os níveis pré-lógicos (dos deles e dos nossos) que moldam os nossos e os seus corpos, diferenciando a percepção das pessoas, pois, para os Mbyá - e para quase todos os originários - , a floresta é a roça cultivada pelos deuses e pelos ancestrais, mas também habitada por seres malignos, onças e feiticeiros transmutados, a colocar à prova os que se arriscam adentrar em seus domínios. Há que se "negociar" com tais entidades para circular ileso (sem adoecer ou ser devorado) e para obter os recursos de sustento pela caça, pesca e coleta, ou mesmo para adquirir poderes inspirados, forças verdadeiramente "mágicas". 
Para os eurodescendentes, as florestas são espaços caóticos e fora do controle humano, pura "natureza" enquanto fonte de matérias-primas em estado bruto, exatamente porque não temos intimidade com sua ecologia. Sem pensar muito, nossa imaginação urbana povoa a floresta com animais peçonhentos (a cobra da tentação bíblica), feras sanguinárias e, outrora, índios selvagens, primitivos e canibais. Claro, os Mbyá respeitam as florestas, principalmente evitando transitar nela à noite, porque lá habitam diversos seres maléficos que se pode evitar a partir de alguns dispositivos rituais e técnicos, mas isso também tem um sentido cosmo-ontológico melhor avaliado desde a metáfora mítica da cosmogênese e da cosmogonia Mbyá.

A existência humana Mbyá é vivida enquanto reprodução do ato básico mesmo de criação da Terra Nova (Yvy Piau) por Nhanderú Vuçu: o Caminhar (CADOGAN, 1953). O Deus Mbyá criou o Mundo atravessando caminhos originários e sendo seguido de perto por entidades maléficas e avarentas, a tentar desviar seu rumo sagrado nas bifurcações do percurso, onde foram colocadas provas e armadilhas, tentações a neutralizar seus propósitos criadores. Hoje, o Jeguatá Tape Porã seguido por José Cirilo é percorrido dessa mesma forma, apenas com a diferença de que os seres maléficos originários foram substituídos pelos agentes do mundo e das instituições juruá.

Assim como Nhanderú criou as coisas do mundo caminhando pela superfície terrestre, a caminhada de José Cirilo é cheia de realizações, mais singelas se comparadas com as divinas, mas grandes quanto ao humanamente possível. Começando pelos seus cinco filhos, de que ele tem orgulho por ter ajudado a parir e a educar no sistema tradicional, mas também investindo em sua escolarização junto aos brancos. Destacou-se como liderança política desde cedo, tornando-se reconhecido na Argentina e no Brasil como capaz de manter a Teko Porã (Bem viver) nas aldeias em que foi cacique e também muito eficiente nas relações com os brancos.

Enquanto liderança, José Cirilo Morinico começou muito jovem: tornou-se cacique aos quatorze anos de idade na Tekoa Sapucaí (Municipalidad Hipólito Herigógine, Misiones, Argentina), habitada, então, por dezoito famílias. Depois foi morar na Tekoa Marangatu, onde fez aproximação com o filósofo e líder espiritual Mbyá Lourenço Ramos, 
com quem aprendeu que as lutas políticas devem se fazer, sempre, sobre bases espirituais/rituais. Lá ele se tornou cabo, um dos cargos dos Xondaro Marangatu (guardiões da tradição) que resguardam a segurança e a ordem dentro e fora das comunidades. Desde então, tornou-se uma liderança que se salientou por sua proposta Cosmopolítica, sempre se precavendo com cerimônias na opy para cada embate a ser enfrentado com os jurua kuery para obter reconhecimento e execução de políticas especiais.

Desde então, tornou-se liderança preocupada em acompanhar de perto os projetos e ações realizados por instituições públicas, privadas e não governamentais dentro das aldeias e/ou envolvendo os próprios indígenas. Tornou-se muito eficiente em tratar com agentes institucionais, tanto para adaptar projetos distorcidos, como para cobrar, de maneira ríspida, falhas e demoras na realização dos objetivos propostos. A rispidez no trato inicial com os brancos é sua norma: eu mesmo fui submetido a diversas provocações e cobranças quando nos conhecemos. Apenas depois foi que ele me disse estar me testando, para reconhecer minhas verdadeiras intenções e minha capacidade de suportar dificuldades. Assim, sempre foi sensível para reconhecer e prestigiar a aliança com brancos motivados pessoalmente por princípios ontológicos parecidos com os dele.

Um elemento marcante para desencadear a Bela Caminhada da Tradição de José Cirilo e de sua família em direção ao Brasil foi o nascimento e a morte prematura de seu filho primogênito. Foi na Tekoa Marangatu, e José Cirilo tinha 15 anos de idade. José Cirilo lembra com consternação desse momento de sua vida, pois sua luta se tornou muito mais potente depois. O nascimento de seu filho foi o evento que o fez adotar o caminho da concentração "espiritual". Sua atenção e sua consciência se voltaram para pensar e entender o mundo, questionando o que é a vida na Terra. Seu propósito tornou-se a busca pela melhor forma de viver tradicionalmente e garantir um futuro feliz para seu filho e demais familiares. E aumentou sua concentração nas cerimônias tradicionais realizadas dentro da $O p y$, onde sua mãe e seu irmão mais velho se tornaram os seus conselheiros e mestres do bem viver. Jamais saía da aldeia, a não ser para fazer suas expedições ao mato.

Sobreveio a morte de seu filho, e José Cirilo não se alimentou 
durante duas semanas, chorou durante um mês e, ao final, também adoeceu. Ele ficava vagando nas matas a esmo, pensando e chorando. A debilidade corporal produziu nele efeitos parecidos com os descritos na etnologia como os advindos ("delírios") de sofrimentos extremos, considerados como necessários à iniciação xamânica em muitos grupos ameríndios. Foi, então, em estado de debilidade física que José Cirilo ficou em estado alterado de consciência e conseguiu, finalmente, conversar com Deus. Para tranquilizar sua dor e ter força espiritual, José cirilo recebeu de Nhanderú um Canto Sagrado (Poraí Mara'ey), que passou a ser uma de suas armas pela busca da felicidade nesta Terra.

Sua conversa com Nhanderú também lhe rendeu a indicação para que ele e sua família viessem em direção ao Litoral Atlântico, para que buscassem felicidade no Brasil. Foi assim que se reforçou seu Jeguata Tape Porã na direção do sol nascente, morada de Karai.

\section{José Cirilo, posição liminar em reforço ao Mbyá Rekó marginal}

Além do fato de estar enfraquecido e doente antes de falar com Nhanderú, José Cirilo também compartilha com o sistema xamânico ameríndio uma incerteza quanto à sua origem familiar e étnica. Há uma tendência de que pajés e xamãs apaguem ou desvirtuem parte de sua biografia e diluam suas relações de parentesco, ficando fora das redes de desavenças interfamiliares e interlocais para assumir uma posição pantribal, tendo algo como um passe-livre para circular em territórios alheios e chegar em aldeias desconhecidas. Em contraponto, ficam completamente vulneráveis em casos de acusação de feitiçaria, podendo ser mortos e trucidados sem oposição.

No trato íntimo e solitário com o ambiente florestal, existe outra das divergências que marcam a trajetória de vida de José Cirilo dentre os próprios Mbyá, do que ele parece ter uma mistura de orgulho e estranhamento. Há, entre os Mbyá, aqueles que questionam a pureza de estirpe Guarani de José Cirilo, pois, na juventude, ele tinha um comportamento demasiadamente arredio e aguerrido, principalmente contra os brancos ("Ele é meio Guayaqui, lá das matas do Paraguay!"). Ele relata, também, que existem divergências entre os Karai e Kunhã-Karai 
que fazem a nominação das pessoas (Nhemongaraí Vae), pois não sabem definir se sua alma veio do leste (Karal), do zênite (Kuaray) ou do oeste (Vera). Uma vez, José Cirilo escutou de um professor Mbyá bilíngue a estranheza e a admiração pela sua forma diferente de comportamento e de luta cosmopolítica, chegando a compará-lo - em correspondência para os Mbyá, pela divergência de posição - ao profeta Moisés, com sua Tábua de Mandamentos aos hebreus.

Não é absurdo comparar a trajetória divergente de José Cirilo com a do feiticeiro cético Quesalid, autobiografia kwakiutl trazida por Franz Boas e analisada estruturalmente como exemplo no clássico estudo intitulado $O$ feiticeiro e sua Magia, de Lévi-Strauss (1974). Há divergências nas respectivas trajetórias de vida em relação às normas vigentes, ambos céticos frente à sua própria tradição, e numa certa marginalidade que compartilham quanto ao conjunto institucional de suas respectivas coletividades. Lévi-Strauss reconhece esse traço como uma característica estruturante da magia - e, incluo aqui, também do reconhecimento e prestígio político entre os Mbyá) - já que ninguém pode saber/controlar a fonte de onde retira seu poder espiritual. José Cirilo não tem nada de feiticeiro, até porque a feitiçaria é repudiada enquanto prática oposta à busca pelo mboraiu (compartilhamento, comensalidade) que se coloca como prática ideal ao Aguyje; mas ele reproduz o ceticismo frente aos falsos guias espirituais, buscando desbaratar seus truques, sempre conclamando a centralidade da dimensão "espiritual", das Falas Inspiradas dos mais velhos e dos rituais dentro da Opy.

Aqui é oportuno voltar ao habitus perceptivo dos Mbyá e a seu paralelismo com as correntes teóricas hermenêuticas e fenomenológicas, ambos compartilhando a preocupação no captar o aquém e o além do real e do imaginado, algo que abala nosso positivismo científico enquanto uma metodologia ingênua da verdade, pois o empirismo e o realismo produzem cegueira e se amedrontam com as contingências, posição racional oposta à dos Mbyá-Guarani. Crapanzano (2005, p. 367) pergunta se "estamos cultural e historicamente vinculados ao medo e à ansiedade perante a possibilidade imaginativa?". Por diversas vezes, neste texto, usamos do recurso de instigar a imaginação do leitor, a fim de abalar nossa posição enquanto vítimas de uma "epistemologia puritana da 
presença". Crapanzano, como os Mbyá, parte de uma crítica radical aos pressupostos empíricos que removem o vago e o inarticulado de nossa vida mental. $O$ valor da imagem, como elas são poeticamente enunciadas pelas Belas Palavras dos Mbyá, está no halo, na aura e na penumbra que as rodeiam.

José Cirilo é um fenomenólogo originário, nativo por "natureza", pois não precisou passar pelo aprendizado intelectual na academia para seguir de forma mais espontânea e genuína os mesmos princípios. É também assim para os demais Mbyá. Seu pensamento está voltado ao aquém e ao além do já conhecido, fixado no presente e sempre atento à aura imprecisa e obscura, mas componente necessário de qualquer pensamento, percepção e experiência. A periferia da consciência é o substrato invisível sobre o qual se precipitam o imaginário e o simbólico, dizem os fenomenólogos. É a função do Nada, segundo Heidegger (cf. CRAPANZANO, 2005, p. 376), o pano de fundo de toda nossa existência: "o nada é o que torna possível a revelação de nossa existência humana como ela é". Aterrorizados com o Nada, colocamos nossos conceptos e nossos perceptos em suspenso. Assim também ensinam os Mbyá, embora eles não demonstrem terror, mas admiração, ao mesmo tempo mórbida e poética, pelo Nada.

A posição de José Cirilo é uma radicalização dessa proposta, mesmo depois de conviver intimamente com as categorias linguísticas e mentais argentinas e brasileiras, herdeiras da cultura euro-americana, em que se pratica a ênfase nos elementos entendidos como mônadas, em detrimento das relações entre eles. A epistemologia corporal dos Mbyá segue mais o modelo chamado por Crapanzano (2005) de "perceptivo" (eis o perceptivismo novamente), que, ao contrário, valoriza o aquém e o além mais do que os elementos, prioriza a relação entendida enquanto definidora dos elementos relacionados. Enquanto nossos sistemas classificatórios e nossas categorias acentuam a coesão, o modelo perceptivo Mbyá procura as elipses, valoriza as interrupções e procura aprender com as pausas e com o silêncio. É no espaço intersticial da imaginação, é no horizonte imaginativo que eles e nós conseguimos nos colocar no "entre" o material e o espiritual, no "entre" o ser e o nada. No caso dos Mbyá, melhor dizer: entre o Estando e o Devir.

É pela leitura de Crapanzano que se usa a ideia de José Cirilo 
enquanto um personagem e agente liminar, não pela posição antropológica tornada clássica desde Victor Turner, que enfatizava mais a estabilidade gerada pelo ritual do que a instabilidade liminar e seu poder disjuntivo. É necessário dar estatuto teórico aos propósitos de um pensamento como o dos Mbyá, que se anula pela procura do que está fora dele. José Cirilo surgiu liminar numa coletividade étnica que é igualmente marginal e que se faz pela procura da manutenção de sua marginalidade. Assim, José Cirilo é o exemplo radical de uma epistemologia liminar, pois os Mbyá estão sempre atentos às disjunções que nunca desaparecem por completo, mesmo antes ou depois dos rituais. O pensamento Mbyá reconhece que em toda troca social há um momento disjuntivo, há o suspense e o risco da passagem, momento assintótico da travessia em que se experimenta o perigo, a ansiedade e o terror - armadilhas deixadas no Jeguatá Tape Porã por deuses, demiurgos e seres malignos para colocar os viventes à prova em direção à imortalidade.

As Belas Palavras e o Auvy Rapitã exaltam a imaginação surgida nas lacunas e nos momentos disjuntivos do não-ser que pontuam a vida social e cultural dos Mbyá. Tal qual colocado por Crapanzano (2005), José Cirilo, enquanto um Mbyá diferenciado, enaltece os momentos assintóticos de passagem liminar dentro da Opy ou em seus retiros florestais, situações vividas enquanto oportunidades para expandir seu horizonte imaginativo, aprendendo com os sentimentos de ameaça, fascínio e encanto em cada prova de sua caminhada terrestre. E, tal qual o caçador que retorna de sua expedição "liminar" na floresta com a carne da caça a ser compartilhada e abastecer o grupo, José Cirilo valoriza sua procura pela liminaridade como fonte legítima da Sabedoria Ancestral Guarani, compartilhando-a e sendo um de seus principais defensores entre os Mbyá, lutando politicamente junto aos brancos, guiado pela imaginação onírica e estática sempre procurada antes, durante e depois, procurando indicações e presságios quanto às decisões e ações despertas.

Historicidade pós-colonial e transnacional do Mburuvichá José Cirilo 
José Cirilo é um representante típico de nossa época atual, liderança originária que ocupa uma posição muito bem definida e reconhecida dentro de contextos locais, regionais, nacionais e internacionais. Ele é um exemplo claro daquilo que a literatura antropológica tem chamado de transnacionalidade (HANNERZ, 1997), enquanto condição contemporânea da globalização. Ele representa a permanência da alteridade radicalmente diferente dos Mbyá dentro de contextos culturais e sociais adversos e marcados pela mistura e pelo hibridismo. Eles se mantêm radicalmente diferenciados, apesar das forças históricas de genocídios e etnocídios promovidos por nossa civilização, apesar de não existirem mais florestas preservadas e apesar de terem que morar junto ao cinturão urbano. Seus antecedentes já habitavam a mesma região em que hoje estão distribuídas suas comunidades, milênios antes que se criassem os países modernos. Por isso, os Mbyá são internacionais e transnacionais por definição, inclusive porque eles não se mostram interessados em criar uma nação própria e continuam sua itinerância liminar em todos os lados da Tríplice Fronteira (Brasil, Argentina e Paraguay).

José Cirilo é um homem de seu tempo, que é capaz de reformular constantemente suas convicções, pressionado pelas forças transnacionais do Capitalismo. Ao longo dos anos - pelo que ele mesmo relata e pelo que pude observar ao longo de décadas, acompanhando suas "lutas" travadas na relação com as burocracias institucionais e com a má vontade dos agentes responsáveis -, ele foi sendo agitado pelas forças dos eventos e conjunturas vividas, tendo que acionar sua historicidade para dar conta das novas condições da realidade, agora amplamente compartilhada com o mundo dos brancos. Nada de desalento frente ao colapso trazido pelos juruá kuery, pelo contrário: estímulo para reforçar sua autoestima étnica, haja visto que ele e os Mbyá realmente acreditam e esperam o fim deste Segundo Mundo ( $Y v y$ Piau), mas seguem o preceito de que são superiores aos brancos porque se mantêm mais perto e foram escolhidos pelos deuses para retardar essa derradeira destruição terrestre.

A condição de estar na história, de ter historicidade, foi negada aos "nativos" pela antropologia moderna, supondo que sociedades "primitivas" entraram em colapso com a colonização europeia. No caso dos Guarani, foi suposto que desapareceram pela aculturação da 
catequese jesuítica, pelas mortes em batalhas de fronteira, pela Guerra do Paraguay e pela mestiçagem. Em meados do século XX, a presença dos Guarani na periferia da cidade de São Paulo só conseguiu ser explicada, pelo modelo teórico da época, enquanto resultado de um processo profético de resistência (SCHADEN, 1959). Naquela época, vigorava uma ideia de que havia a exacerbação religiosa pela procura da Terra-semMal como resultado de desordem social e última forma de resistência ao avanço civilizado. Contando hoje com os parâmetros pós-coloniais, que acusam a tendência de epistemicídio praticados pela antropologia iluminista sobre seus grupos estudados, somos capazes de buscar uma maior simetrização entre os interlocutores, pondo em prática uma antropologia dialógica e reversa.

A trajetória de José Cirilo destrói qualquer confiança residual que exista sobre alguma suposta incapacidade mental dos originários. Tomese como exemplo a sua relação com a educação escolar. Sua primeira tentativa foi com oito anos de idade, quando começou a ter aulas numa escola branca existente junto à Tekoa Txapy (Misiones, Argentina), onde residia então. Por causa dos destratos sofridos por preconceito dos colegas brancos, ele abandonou a escola ainda no primeiro mês e não quis mais voltar. Reverteu seu interesse no aprendizado e na valorização da sabedoria de cheramoi e chejari (nossos avôs e avós). Tornou-se convicto de que os Mbyá possuem seu tipo próprio de educação, que é o convívio familiar e aldeão junto aos mais velhos, além da central importância da $O p y$, onde as crianças aprendem sobre a Verdadeira Sabedoria. Assumiu uma postura crítica frente à possibilidade das escolas virem a suprimir a tradição e marginalizar os mais velhos, levando os estudantes a se transformarem em brancos, terminando com os Mbyá.

Sua postura tinha fundamento, considerando-se a conjuntura das políticas escolares existentes no período de sua infância na Argentina e também no Brasil. Era o começo da década de 1980, período de vigência das Ditaduras Militares e momento ápice de aplicação do modelo monocultural vigente desde o nascimento do Brasil e da Argentina. Durante todas as fases das políticas indigenistas anteriores, as escolas indígenas foram criadas como instrumentos de aculturação e de integração dos indígenas como mão-de-obra camponesa. No Brasil, como na Argentina, os objetivos eram a completa integração econômica 
das comunidades indígenas e a assimilação completa de sua população à "sociedade nacional" pela mestiçagem.

A influência das transformações nas legislações internacionais pelo crescente reconhecimento e respeito às diferenças raciais, étnicas e de gênero - depois da Segunda Guerra Mundial e da pressão social dos movimentos Negro, Hippie e Feminista Norte-Americanos -, junto à pressão gerada pelos movimentos sociais e pela mobilização indígena internas no país durante a constituinte, fizeram com que o projeto nacional assumisse uma nova configuração desde a vigência da Constituição Federal Brasileira de 1988 (CF 1988). Ao menos formalmente, agora a sociedade brasileira está definida como a comunhão harmônica de seus grupos formadores, seguindo o modelo pluriétnico e multicultural, ficando reconhecida a dívida histórica do país para com os povos originários, estabelecendo o pleno reconhecimento de seus territórios tradicionais e o atendimento, através de políticas especiais e diferenciadas, nos aspecto de sustento, saúde, infraestrutura e educação.

Passou-se mais de um quarto de século de vigência da CF 1988 e poucas políticas foram efetivamente implantadas segundo as demandas diferenciadas das comunidades originárias, mas observamos lentas transformações. Lembremos os referenciais teóricos utilizados por João Pacheco de Oliveira (1996), quase uma década depois de 1988, para demonstrar o quanto o "regime" vigente no Estado Brasileiro tem vícios coloniais ainda preservados. Há, assim, um grande descompasso entre o que estabelece a CF 1988 e as práticas administrativas efetivamente realizadas pelos poderes legislativos, executivos e judiciários em âmbitos municipais, estaduais e federal em prol das comunidades indígenas.

Tudo isso para dizer que José Cirilo manteve sua posição crítica ao papel das escolas indígenas até uma década atrás, exatamente porque as escolas ainda se mantinham rígidas na reprodução das estruturas burocráticas formais, e no não envolvimento dos indígenas na sua formulação e gestão, faltando, inclusive, professores indígenas. A tese de Maria Aparecida Bergamaschi (2005) foi produzida sobre material empírico coletado na escola existente na aldeia atual de José Cirilo (Tekoa Anhetengua, Lomba do Pinheiro, Porto Alegre) até 2005, e ela finaliza seu trabalho cética quanto à possibilidade de se criar, um dia, uma Escola 
Mbyá-Guarani.

No entanto, lentas alterações foram produzidas por um setor específico da Secretaria Estadual de Educação, responsável pela criação de Escolas Bilingues nas últimas décadas e também preocupada com a adequação dos currículos, a capacitação e a contratação de professores e funcionários indígenas. Vale destacar o nome do colega Rodrigo Venzon, que atua na criação de escolas efetivamente diferenciadas - inclusive para implantar o prédio amplo de uma nova escola dentro da aldeia Tekoa Anhetengua, liderada por José Cirilo, fato que aconteceu há apenas três anos e do qual hoje o cacique tem muito orgulho, exatamente porque houve a participação dos Guarani em todas as etapas, desde seu projeto até a atual contratação de indígenas para seu funcionamento.

Nesta mesma última década, José Cirilo demonstrou uma radical alteração em sua postura pessoal sobre a escolarização, chegando a pagar cursos técnicos em escolas particulares para seus filhos, além de investir em um deles para se tornar motorista com carteira expedida pelo órgão oficial. Isso é um exemplo de historicidade, é a demonstração de que José Cirilo e os Mbyá estão incluídos no tipo performático (traço ligado ao perceptivismo corporal e à liminaridade tratados anteriormente) de sociedade, segundo a definição de Sahlins em I/has de História (1997). As situações conjunturais são vividas por José Cirilo segundo se apresentaram as circunstâncias, ora permanecendo rígido na tradição para poder inovar (no caso, recusando a escolarização como forma de obter reconhecimento oficial em pé de igualdade, enquanto um "diplomado" em sua própria tradição), ora mudando sua tradição para poder ser o mesmo (hoje ele mesmo está se escolarizando, se adaptando aos novos tempos, quando, diz ele: "se matam os índios não mais com doenças ou com armas de fogo, mas com canetas"). Seus dedos correm soltos agora nas telas de telefones celulares, onde posta orgulhoso os momentos de sua vida e os projetos nos quais tem participado em redes sociais. Lembremos que estamos falando de alguém que teve sua primeira fase de vida apenas nas matas e florestas e foi capaz de superar todos os colapsos gerados pelo convívio com nossa civilização. E ainda tem fala trilíngue (Guarani, Espanhol e Português).

A recusa pela escolarização foi a primeira grande divergência de caráter político em sua vida contra as instituições juruá, ainda na infância. 
O repúdio etnocêntrico dos estudantes argentinos fez ele se voltar para o âmago do Mbyá Reko, identificando que, em sua aldeia, não há escola separada da casa ou da igreja ou do hospital. Tudo existe em equivalência dentro de sua própria tradição, com a diferença de que, para eles, tudo faz parte de tudo, no holismo Mbyá-Guarani. Foi com essa postura que ele passou a enfrentar os agentes assistenciais ou interventores, que circulavam pelas aldeias desenvolvendo projetos destinados aos "índios". Ao invés de ter vergonha, sentia orgulho por não ter estudado, respondendo sempre que os Mbyá também possuem suas formas próprias de fazer e saber, tão válidas quanto as dos brancos, e que ele sempre foi um estudioso e interlocutor necessário para aceitar a atuação de forasteiros dentro da comunidade, acompanhando e influenciando de perto a execução dos seus projetos. José Cirilo aparece, assim, como exemplo vivo de uma postura originária anti-colonial, do colonialismo que perdura ileso na maneira assistencialista e arrogante como as instituições continuam operando.

Imbuído de seus propósitos cosmopolíticos (ele só passou a utilizar esse termo faz bem pouco tempo, por influência do diálogo com antropólogos), depois da morte do filho e de receber de Nhanderú o seu canto sagrado e a indicação do rumo a tomar, atravessou o Rio Uruguai e entrou no Brasil, ficando acampado com a família às margens de uma rodovia estadual, no trevo que dá acesso à cidade de Santa Rosa. José Cirilo chegou no Rio Grande do Sul provocando repercussão. Mesmo sem ainda falar direito o Português, deu uma entrevista gravada e reproduzida pela sucursal local de tevê da Rede Brasil Sul (RBS). Sua forma enfática de reivindicar direitos originários e sua boa articulação no falar um "portunhol" (mistura crioula do Português com Espanhol) inteligível e claro chamou a atenção do Procurador da República sediado naquela região, na época o Dr. Marcelo Beckhausen, que chamou José Cirilo para uma audiência. Desse encontro nasceu, então, uma relação duradoura de apoio promovido pelo Ministério Público Federal (MPF) em prol da causa dos Mbyá-Guarani no Rio Grande do Sul. Lembremos que estamos tratando do período de vigência inicial da CF 1988, e esse órgão foi um dos primeiros a encampar a questão indígena e a exigir as transformações necessárias na estrutura do Estado Brasileiro para executar políticas especiais e diferenciadas segundo seus usos e costumes. 
José Cirilo foi um dos primeiro líderes Guarani a levantar a voz e alertar os poderes públicos nacionais e regionais sobre a precariedade de condições em que vivem os Mbyá em situação de acampamento na beira das estradas. Ele mesmo viveu durante meses embaixo de lonas plásticas pretas, dependendo dos parcos recursos advindos da venda de artesanato ou da doação feita por particulares e instituições assistenciais. Num primeiro momento, caiu sobre sua família a acusação de serem estrangeiros, de serem índios argentinos ou paraguaios que chegaram para pegar terras privadas de brasileiros. Como dito anteriormente, a cosmogeografia originária é completamente desconsiderada por essa noção ideológica torpe que desconhece que "nossa" nação moderna foi criada sobre a expropriação - um "grande confisco", nos termos de Rui Ruben Ruschel (1994) - das territorialidades ameríndias, outrora compostas por extensas redes de mobilidade ligando parentelas e aliados por centenas ou milhares de quilômetros, do leste do Paraguay (Yvy Mbté, Centro da Terra) e norte da Argentina (Para Miri), chegando ao litoral (Para Guaçû) através de comunidades distribuídas no Sul e Sudeste brasileiros. Depois de 1988, os originários tiveram restituídos seu direito de ir-e-vir, gerando a proliferação de acampamentos antes reprimidos pelo órgão indigenista responsável (FUNAl, Fundação Nacional do Índio), ou pela ação direta da polícia civil e militar. O problema da marginalidade (liminaridade) dos Mbyá saiu da invisibilidade nesse contexto.

A articulação com o MPF rendeu a José Cirilo a providência da FUNAI em dispor de alguma terra para seu assentamento familiar, mais próxima ao litoral e também da Capital do Estado, Porto Alegre. Ele e sua família se mudaram e ficaram acampados oito meses na aldeia da Varzinha, Município de Caraá. A única diferença da situação anterior foi o fato de que ele e sua família saíram da beira da estrada para se manterem de forma precária, novamente, embaixo de lonas pretas junto ao mato. Sabemos que, mesmo possuindo muita mata, a área da Varzinha é composta por floresta desbastada e em processo de regeneração (mata secundária), quase não tendo caça, e o riacho que existe é cheio de cachoeiras e sem muitos peixes. A família e José Cirilo chegaram com poucas sementes, sem as mudas tradicionais, e não conseguiram fazer roça. O ambiente também é um pouco diverso das matas de Misiones de onde vieram, de maneira que chegaram sofrendo muitas dificuldades de 
sustento. Ficaram esperando o apoio da FUNAI para construção de uma casa, mas nada aconteceu.

Esse período passado na Varzinha tem uma dupla importância na trajetória da vida de José Cirilo. Em primeiro, porque repentinamente ele voltou a sofrer as dores emocionais pelo filho morto, lembrando constantemente a tragédia e a alegria perdida. Como de costume, nos momentos críticos, José Cirilo voltou a percorrer as matas e a procurar seus "templos" da floresta para cantar seu canto sagrado e receber mais força de Nhanderú. Diz ele que "rezou" concentradamente dentro da mata, pedindo ajuda de Deus, até que repetiu três vezes a mesma pergunta: "Meu pai, por que estou sofrendo tanto?". Então, Nhanderú respondeu: "Meu filho, tu não estás sofrendo. É que Eu estou te ensinando a reconhecer o que são as pessoas e de como tu deves lidar com elas!". A mensagem de Nhanderú ficou clara na mente de José Cirilo: ele estava aprendendo a conhecer as pessoas e de como lidar, principalmente, com os brancos. Ele chegou à seguinte conclusão: "Daí em diante eu devo ir na frente do meu Povo Mbyá!". Deus Ihe deu uma missão, e ele se sentia competente para corresponder às ordenações divinas.

A segunda importância, derivada diretamente da primeira, foi o fato da Aldeia da Varzinha ser mais perto de Porto Alegre, permitindo a José Cirilo chegar à procura de responsáveis pelas causas indigenistas, também para "caçar" aliados e instituições que pudessem ajudar. Não poderia ser de outra forma: José Cirilo chegou ao encontro dos poucos abnegados que lutam historicamente pela causa indígena e Guarani na região Metropolitana de Porto Alegre, muitos deles egressos da extinta Associação Nacional de Apoio aos Índios (ANAI), que teve forte atuação no Estado do final da década de 1970 até o ano de 1983, ano de sua extinção. Lá atuaram Rodrigo Venzon (referido acima, ainda na ativa na SEC), Ignácio Kunkel (ainda na ativa junto à Secretaria Estadual de Agricultura), Maria Inês e Ivori Garlet, o segundo lamentavelmente já falecido, além de Hilda Zimerman (também lamentavelmente falecida).

Com todas e todos com quem fez contato, José Cirilo expressou reclamações quanto às condições precárias em que se encontravam as comunidades Mbyá-Guarani no Brasil. Ivori Garlet era estudante de história da Pontifícia Universidade Católica do Rio Grande do Sul (PUC-RS) e também interessado em realizar estudos e aproximação existencial 
junto aos Guarani. Por isso, ele promoveu a aproximação de José Cirilo com o ambiente universitário, organizando uma reunião com a Professora Dra. Maria Cristina do Santos, que Ihe expressou reconhecimento por sua origem étnica e por seu otimismo e lhe desejou sucesso em suas lutas futuras. José Cirilo também procurou outras parcerias institucionais, como foi o caso do Conselho de Missão entre Índios (COMIN), órgão da Igreja Luterana do Brasil. Ele visitou a sede da entidade no Morro do Espelho (Município de São Leopoldo) e fez contato com outros parceiros que se mostraram importantes em momentos futuros, como Mozart Dietrich, Maria Inês Gallet e Lúcio R. Schwingel.

José Cirilo estava dando um novo passo em sua jornada do Jeguatá Tape Porã. Ele procurou a todos os citados e a outros no intuito de reproduzir seus propósitos anti-coloniais, reclamando sempre contra o protecionismo e o intervencionismo brancos na aplicação de projetos cujos beneficiários são, em última instância, eles mesmos. Desde então, sua caminhada passou a defender e a procurar recursos para a realização de sucessivas reuniões de articulação entre os membros de todas as comunidades Mbyá-Guarani, chamadas Nhemboaty. Seu discurso anticolonial é marcante: "O importante é nós fazermos reuniões e nos organizarmos! Não precisa o branco orientar o índio!". José Cirilo deixou marcas permanentes na sua luta pelo protagonismo e pela autodeterminação étnica. Até hoje, as comunidades Mbyá continuam fazendo reuniões de articulação, como exemplificam as que se realizaram neste último ano, integrando as aldeias do litoral (com o apoio da EMATER e do PGDR), das quais ele também participou.

Para ele, o importante são os aliados, e instituições fornecerem subsídios para que eles próprios e suas lideranças dialoguem e se articulem, substituindo a intervenção das entidades pelo trabalho feito por sua própria organização interna. Neste período, ele também passou a contar com o importante apoio institucional e mesmo pessoal da antropóloga Dra. Mirian Chagas, atuante enquanto servidora da Procuradoria da República e sempre pronta a intervir em situações de conflito e ruído nas relações dos Mbyá com os membros da sociedade envolvente. Esse foi um momento de alto rendimento nos propósitos de José Cirilo para sensibilizar os agentes e entidades no sentido de reconhecer e apoiar a autodeterminação Mbyá e acatar as decisões 
pactuadas entre as diversas comunidades em contínuo processo de reunião e articulação.

José Cirilo diz que, nesse momento, ele tinha aberto o caminho de trabalho e de luta, mas que era chegado o momento de repassar a tarefa para outras lideranças mais jovens. "Eu parei”, disse ele. O momento de grande intensidade e desgaste de energia pessoal na procura de agentes e entidades obteve resultados muito positivos, mas teve como consequência, também, a sua debilidade corporal. José Cirilo adoeceu e ficou de cama por três meses seguidos. O mais interessante é que ele não esconde a existência de dimensões imanentes, consideradas "ocultas" por alguns Guarani, para explicar o tipo de doença que teve. Ele diz que foi enfeitiçado por inveja de outros Guarani por seu papel de evidência em fazer a articulação étnica e a mediação política com os brancos. Ele teve um palito magicamente instalado na sua coluna vertebral, na região lombar, feitiço que tinha por objetivo provocar sua morte, o que quase aconteceu. A vida de José Cirilo é a reprodução do caminho terrestre em seus fundamentos cosmológicos, cheio de armadilhas e sofrimentos intencionalmente colocados para testar os propósitos e ensinar o caminhante. "Mas Nhanderú está sempre me cuidando", diz ele, recordando o acontecido. Finalmente, conseguiu encontrar uma Kunhã Karai Pita'í Vae (liderança espiritual feminina tiradora de feitiços), que fez o diagnóstico e conseguiu remover o palito mágico. "Agora tu vais viver sempre com saúde", disse ela por fim.

Será preciso deixar para outra oportunidade desdobrar consequências teóricas importantes sobre a existência de feitiços entre os Mbyá-Guarani atuais, em referência ao que se publica na etnologia sobre os Guarani (do papel). Interessante a abordagem de Carlos Fausto (2005) sobre uma plausível "desjaguarização" da "religião" Guarani, atribuindo influência cristã no estabelecimento de uma Ética do Amor "passiva", expressão utilizada pelo autor para traduzir o termo Mboraiu (preferimos "compartilhamento e comensalidade das dádivas trocadas", no sentido de Marcel Mauss, 2003). José Cirilo nada tem da passividade e da amabilidade supostas como deturpações advindas do Cristianismo à igualmente suposta "religião" Guarani. Já é difícil aceitar a tradução das Belas Palavras e dos Pensamentos Inspirados enquanto manifestações "espirituais" (é assim que os Mbyá traduzem), ainda mais supor que exista 
um campo religioso dissociado das demais esferas da vida ordinária e extraordinária. A referência ao holismo perceptivo e corporal Mbyá deve falar mais alto.

Em síntese, não há uma correspondência evidente entre uma suposta Ética do Amor e as habilidades e os poderes obtidos direta e penosamente de Nhanderú por José Cirilo, tendo recebido poderes visionários para discernir em quais pessoas é preciso e vale a pena investir para "conquistar seus corações" aos propósitos da sua cosmopolítica. Consideramos que a chamada Ética do Amor é outro dos desvios gerados pela hermenêutica religiosa a especular sobre os Guarani de papel. José Cirilo é de carne e osso, e sua vida é cheia de percalços e desafios, cheia de sobes e desces, como exemplifica o que já foi narrado até aqui. Lembremos que há uma dualidade marcante na configuração da pessoa Mbyá, um pólo considerado divino, celeste ou espiritualizado voltado ao Bem, à alegria, à Saúde e ao Mboraiu (Nhe'e, traduzido simplificadamente como "alma-palavra") e outro pólo terrestre, marcadamente corporal e animal (Acygua), espiritualmente voltado para o Mal, ao desejo sexual, à tristeza, à doença, às desavenças, à inveja e à morte corporal. O primeiro pólo tem no Aguyje sua mais sublime realização, enquanto a outra está ligada à condição existencial decaída do Teko $A x y$, traduzida pela etnologia como "alma telúrica", que se transforma em espectro a perturbar a vida noturna dos viventes (Tupichuá).

O convívio mais íntimo com José Cirilo e com outros Mbyá coloca em dúvida a completa correspondência entre o feixe de oposições binárias como acima apresentadas, pois, às vezes, o pólo telúrico assume muito uma dimensão correspondente ao que nós ocidentais chamamos de "profano". Toma-se como referência a observação etnográfica de que, em todas as viagens e visitas feitas às aldeias Mbyá, sempre havia e há momentos iniciais de maior cerimônia e diplomacia, momentos tratados com muita seriedade e pompa ritual. Há também a importância das celebrações, ao cair da noite, dentro da Opy, pólo mais legítimo do Nhe'e (de que nós, juruá kuery, estamos excluídos). No entanto, sempre havia algum momento da viagem ou da semana considerado como a hora das festas e da diversão, movida por banda de jovens ou por um som eletrônico a conduzir a dança por pares no centro do pátio ou do salão. 
Tive e tenho intimidade suficiente para ser convidado a participar em muitas dessas festas promovidas pelos Mbyá, revelando-me certas coisas que geralmente escondem do puritanismo a condicionar os filtros perceptivos de quase todos os brancos. Apenas tenho a revelar que os Mbyá se divertem muito dançando, rindo, namorando, comendo e bebendo.

A própria música tradicional Mbyá é dividida em dois estilos correspondentes (ARNT, 2010): um canto-e-dança considerado mais celeste ou divino (Vero'jy) e outro mais terrestre e profano (Jero'kâ). Fantasias religiosas não podem esconder o fato de que os adolescentes e adultos Mbyá são movidos também pelo desejo de aproximação afetiva e amorosa, movendo-os a organizar bailes, convidando e se alegrando quando recebem a visita de rapazes e moças Mbyá vindos de outras aldeias. $\mathrm{O}$ aparecimento de novos casais e a formação de novas famílias passam inevitavelmente por tais oportunidades. Mesmo considerando as festas enquanto celebrações terrenas, os Mbyá as tratam como oportunidade de alegria e de confraternização - paralelamente similar ao que é tratado pela etnologia amazônica como uma das características complementares à modalidade doméstica de produção, distribuição e consumo, chamado de Regime de Festas, ciclo de momentos de comensalidade com estrangeiros ou afins, momento de expor potenciais cônjuges e também de fazer cunhados, cunhadas, genros e noras.

Tudo isso para dizer que os Mbyá - e, particularmente, José Cirilo - são muito divertidos e se divertem conjuntamente. Sempre estão a trocar comentários irônicos e de duplo sentido, sempre conseguem debochar da própria desgraça em momentos difíceis. Sempre ficam animados ao tocar ou escutar músicas paraguaias, sertanejas e gaúchas. Os jovens da Lomba do Pinheiro, onde José Cirilo é cacique, estão escutando um grupo de "repers" Guarani de São Paulo, muito felizes. A felicidade é a dimensão a explorar na condição de Teko $A x y$, porque ela é saúde; sempre, é claro, evitando os riscos de eventuais excessos que às vezes acontecem, mas que são atribuídos ao descontrole "espiritual" de alguns, e não a algo considerado como consequência inevitável de qualquer confraternização. Não correspondem em nada à imagem criada pelos estudiosos dos Guarani enquanto um grupo étnico vivendo na "humildade e na pobreza", guiados apenas pelo sagrado, a reproduzir os 
sofrimentos de Cristo na terra. Como no Ocidente moderno, os Mbyá vivem uma eterna oscilação em suas vidas entre o "profano" e o "sagrado". Vale ainda trazer uma outra situação especial descrita por José Cirilo para demonstrar que existem motivações ancestrais subjacentes ligadas a algo como um Logos Canibal (VIVEIROS DE CASTRO, 1986). Dentre as tantas dificuldades enfrentadas em cada uma das áreas em que morou, houve um momento em que precisou encontrar alternativa de renda ao sustento alimentar da família na Tekoa Yryapu (Aldeia da Granja Vargas, Palmares do Sul). Considerando-se as dificuldades iniciais de chegada recente, sendo a área ecologicamente bem degradada e ainda sem contar com as cestas-básicas da FUNAI, no desespero, José Cirilo fez a venda de alguns troncos de eucalipto por conta própria com um vizinho da área para obter dinheiro e comprar alimentos. Eis que surgiu uma outra importante personalidade do indigenismo sulista: Francisco Witt, sertanista da FUNAI dedicado ao atendimento prioritário aos Guarani e falante da língua. Chico Witt chegou dentro de um camburão da Brigada Militar, no momento em que Cirilo cortava um eucalipto, a fim de suspender o processo e criminalizar o branco que comprava a madeira. $\mathrm{O}$ argumento era de que a FUNAl sempre deve intermediar qualquer negociação para evitar que os índios fossem enganados. Sobreveio a fúria guerreira de José Cirilo, que relata ter levantado o machado pronto para dar o golpe, dizendo para os ocupantes do carro: "Vocês não arrisquem sair daí de dentro, pois sou Guarani e nós comemos a carne humana dos inimigos morto em batalha!". O alerta surtiu efeito: Chico e os brigadianos foram embora, e a questão foi resolvida depois, de uma forma mais amena.

A fúria viva de um canibal ressurgiu momentaneamente numa situação extrema, em paralelo ao fato de que existem feitiços e formas de evitá-los. A vida é feita também pela dimensão telúrica e pela diversão e alegria que as festas coletivas proporcionam. São exemplos para ajudar a escapar do puritanismo maniqueísta de nossas epistemologias, que acreditam serem os Guarani apenas passivos e moldados pelo Amor Sublime. Isso remeteria nossa análise também à correlação importante a fazer com a temática da lógica da predação, em vínculo com a gramática do parentesco Mbyá. Em síntese, tem-se como plausível a hipótese de que, desde a trajetória de José Cirilo, os Mbyá seguem um pensamento muito próximo ao da "predação familiarizante" (FAUSTO, 2001), muito 
diversa da Ética do Amor. Poderíamos entender o propósito de "conquistar o coração" das pessoas enquanto uma variante da predação transformada em estratégia cosmopolítica? De qualquer maneira, é também instigante a ideia trazida por Phellipe Descola (2002) de "amansamento" em distinção à de "domesticação", considerando ser ela uma forma de tornar familiar uma potencial caça/inimigo pela comensalidade e pelo convívio cotidiano. Nesse sentido, a estratégia de José Cirilo seria um amansamento de nossa "selvageria civilizada"?

Depois dessas abstrações teóricas, tão importantes quanto complexas para serem esgotadas aqui ou em futuros tratados acadêmicos (as coisas do mundo e os Mbyá são inefáveis mesmo!), é preciso voltar ao registro dos momentos seguintes na vida de nosso personagem central. Depois de morar na Varzinha, adoecer e abandonar a frente do protagonismo cosmopolítico Mbyá, ele se mudou com a família para o acampamento do Passo da Estância (Barra do Ribeiro), vivendo novamente na faixa de domínio de outra rodovia, a BR-116. Recuperado de saúde no corpo e na mente, voltou a circular pelas outras comunidades Guarani da região, a fim de constatar como andava o Jeguatá Tape Porã. José Cirilo ficou decepcionado com o que identificou. De um lado, encontrou os Mbyá vivendo na mansidão de sua marginalidade, passivos frente às dificuldades em seus acampamentos provisórios e vivendo do assistencialismo eventual da FUNAl e da doação por entidades e particulares. A grande miséria para ele foi constatar a quase inexistência de Opy nas comunidades que visitava.

De outro lado, encontrou algumas poucas lideranças Guarani articuladas subordinadamente aos auspícios e subsídios de setores progressistas da Igreja Católica brasileira, colocados lado a lado com representantes de outros movimentos sociais em processo de "luta política" por seus direitos sociais. José Cirilo tem um rechaço, desde a infância, contra os padres e sua forma colonizadora de relação com os índios, já dos tempos em que morou na Argentina. Ao falar do assunto, ele argumenta quão errada é a religião Cristã por ser uma religião que cultua o medo, o sofrimento e a dependência espiritual. "É um absurdo cultuar o Deus morto e sangrento em um crucifixo", disse ele certa feita. Ao chegar no Brasil, constatou que as causas levantadas pelos religiosos através do Conselho Indigenista Missionário (CIMI) giravam em torno dos 
Guarani enquanto um povo espiritualizado, nômade e profético, esperando a "terra sem mal" no outro mundo, tal qual o paraíso cristão. É certo que os Guarani e os Mbyá fixam seu pensamento na consciência deste mundo enquanto provisório, transitório, uma cópia degradada das moradas dos quatro casais de deuses celestes (Ta'anga Amba), mas José Cirilo achou demasiado que os religiosos transformassem os Guarani numa legião de Jesus prontos para serem martirizados à obtenção do Paraíso do além. José Cirilo chegou ao Brasil e logo recebeu o chamado de seu deus verdadeiro, Nhanderú, para caminhar na frente de seu Povo Mbyá nesta terra, e não depois da morte. Segundo ele, nunca antes ouvira falar de Yvy Mara'ei (Terra-sem-Mal), e esta Ihe pareceu uma história inventada pelos padres e pelos brancos para justificar o fato grave de que os Mbyá não possuem porções de terras para ocupar segundo seu sistema tradicional.

As divergências de José Cirilo para com a atuação dos representantes da Igreja Católica e do CIMI só foi se agravando; não por implicações pessoais, mas sim por suas divergências quanto aos métodos de aliciamento de certas lideranças Mbyá, disponibilizando recursos para participarem em eventos nacionais e para visitarem todas as aldeias Guarani, no suposto intuito de fazer a mobilização étnica, integrando os Mbyá nos movimentos políticos ao lado de representantes de diferentes setores desfavorecidos. A radicalização ficou maior depois que o CIMI interferiu na criação de três diferentes "produtos políticos", com a cooptação de muitos Mbyá: a) diversos encontros Nhemboaty, congregando mais de centenas de Guarani em São Miguel das Missões e, depois, em São Gabriel, no recém-criado Santuário de Sepé Tiaraju; b) criação de uma Comissão de Terras Guarani, com atuação nos estados do sul do Brasil; e c) declaração de Sepé Tiaraju como herói brasileiro.

Será fácil, ao leitor atento, entender o descontentamento de José Cirilo com esse contexto, recordando seus propósitos cosmopolíticos. Não são religiosos cristãos os que devem guiar os Mbyá, mas sim muita concentração espiritual com os velhos na $O p y$, de onde devem sair as orientações a seguir na "luta política" - luta pelo seu próprio protagonismo, repudiando qualquer intervencionismo alheio aos interesses de suas comunidades. A política não pode e não deve vir antes, pois ela deve ser o resultado das vontades divinas conquistadas de forma 
coletiva e celebrativa. José Cirilo não acredita que o enfrentamento e o acirramento de ânimos nas relações com os brancos possam reverter em bons resultados.

Ele diz que, na política, deve acontecer como na caça: na noite anterior, antes de ir na floresta, o caçador "reza" com os demais membros da comunidade na $O p y$, pedindo licença e negociando com os guardiões das espécies (" $j a)$ para que permita matar os animais membros de suas respectivas "tribos". De forma similar, os documentos coloniais brasileiros abundam em informações de que os Tupinambá só faziam expedições de guerra aos inimigos depois de potentes e exaustivas pajelanças (FERNANDES, 2006), quando os pajés prendiam as almas dos pajés da aldeia a ser atacada, antecipando a vitória mesmo antes do começo das batalhas. José Cirilo mantém essa mesma matriz TupiGuarani de percepção, conduta e suporte afetivo para resistir aos recorrentes embates inevitáveis, como uma liderança originária que enfrenta, de cara pintada e cocar na cabeça, os poderes contrários, instituídos desde referenciais brancos, europeus, mercadológicos, patriarcais, individualistas, privatistas, letrados.

\section{Nhanderú no comando: retomada de terras e conquista dos corações}

Há ainda muito por descrever sobre a vida de José Cirilo Morinico, muitos envolvimentos depois que ele retornou à ativa como liderança em 1994. Rapidamente se integrou ao movimento dos Mbyá na retomada e autodemarcação da área que se transformou na Terra Indígena do Campo Molhado, na época enfrentando capangas armados e munido apenas de facão e arco-e-flecha. Depois, assumiu gradativamente a árdua tarefa de manter diálogo frequente com os juruá kuery em sua diplomacia institucional, tornando-se uma das lideranças centrais dos Mbyá-Guarani no sul do Brasil. Para cada episódio da sua vida se pode escrever um capítulo, e os capítulos dariam livros, um para cada uma das etapas de sua vida. Tarefa postergada para o futuro, até mesmo porque José Cirilo continua aprontando...

A busca para "ganhar o coração" dos brancos não é, entretanto, uma falácia utilitarista de Cirilo Morinico, no sentido de que ela não é 
apenas acionada enquanto estratégia de relação e convencimento: ele apenas quer estender aos outros aquilo que acontece com seus próprios sentimentos e que é central na cosmoecologia Mbyá. Tenho que fechar este texto trazendo o depoimento quanto ao fato de José Cirilo demonstrar profunda afetação (nos termos de Favret-Saada, 2005) pelos acontecimentos do mundo, nos diversos momentos em que pude acompanhar sua caminhada.

O aguerrido Xondaro Marangatu encontra alento para continuar sua luta, sempre medindo a quantidade de momentos de alegria familiar e aldeã que resultam dos confrontos externos por ele vividos. José Cirilo sempre se enche de motivação quando circula pelas aldeias e presencia a alegria de crianças e velhos, mulheres e homens, jovens e adultos. A alegria é o melhor índice de saúde e de bem viver, segundo os MbyáGuarani. Não seria muito errado dizer que a alegria é o principal motor da cosmopolítica protagonizada por José Cirilo.

Numa tarde chuvosa de abril de 2017, eu chegava com José Cirilo e seus filhos na aldeia da retomada em Maquiné (Tekoa Kaa'guy Porã). Fui levá-los e também coletar elementos etnográficos para produzir um laudo antropológico sobre a questão. Ele participa ativamente enquanto liderança na manutenção dessa nova aldeia, uma porção de mata dentro da área de propriedade da Fundação Estadual de Pesquisa Agropecuária (FEPAGRO). A retomada aconteceu um pouco depois que essa Fundação foi declarada em processo de extinção pelo Governo do Estado (RS). Estão sob a ameaça de mandado judicial de reintegração de posse e de subsequente despejo oficial no momento em que escrevo estas linhas. No entanto, estão conseguindo, por enquanto, retardar a decisão judicial desfavorável, contando com um grande número de instituições e grupos de apoio em favor da consolidação de seu ato de retomada.

O cacique da nova aldeia, André Benites, e José Cirilo estão muito tranquilos quanto ao desfecho de seu ato cosmopolítico de retomada. Dizem: "Nhanderú no comando!". Essa frase foi proferida por Cirilo para mim naquela tarde, durante a subida a pé pelo percurso difícil por causa do barro escorreguento e dos cursos d'água que atravessam o caminho. Ele me explicou que fizeram a retomada desde muitos sinais enviados por Nhanderú. Voltamos ao modelo perceptivo de saber Mbyá-Guarani. José Cirilo disse também que os indícios e desígnios divinos se reiteram a cada 
novo momento. Foi me dando exemplos: não encontraram cobras e outros animais peçonhentos e ninguém sofreu qualquer acidente nos meses em que dura a ocupação. Falou da abundância de pássaros e do prazer da melodia de seus cantos. Por fim, falou-me que a alegria das crianças é, de todos, o melhor indício de que Nhanderú continua no comando.

Sob uma chuva fraca, nosso diálogo foi interrompido pelo som do Mbaracá e da Ravé entoando músicas tradicionais que vinham da aldeia acima. A melodia distante chegava aos ouvidos e ficava cada vez mais alta, até que adentramos o espaço da aldeia, em patamar a meia altura da encosta do planalto. Lá, crianças descalças faziam uma roda de Tangará, embaladas pelo som dos instrumentos tocados por adultos, e um homem, com uma vara, estava postado ao centro das crianças. Divertimento geral. Risadas de crianças dançando e escorregando no barro, tentando escapar com agilidade dos "golpes" inusitados do ministrante central. Risadas dos adultos assistindo à brincadeira postados sob a lona de suas casas e barracos improvisados. Depois que o ritual vespertino finalizou, os instrumentos continuaram a tocar e não pararam mais até a madrugada alta, entoada depois do final da tarde no interior da Opy. À noite, a melodia compunha coro com o coaxar de rãs e sapos em meio à escuridão eventualmente iluminada pelas chamas dos fogões familiares. Pude deitar muito próximo da Opy e pude assistir todos entrarem com corpos e roupas limpas, inclusive as crianças que antes estavam embarradas. Meu corpo deitado no chão pode sentir a vibração do solo pelas pancadas de pés em dança e dos taquapu manipulados pelas mulheres. Não sei o quanto isso afetou meus perceptos, pois adormeci sereno nesse embalo.

Pouco depois do amanhecer, no dia seguinte, os instrumentos tradicionais voltaram a tocar, por vezes acompanhados de cânticos, e se mantiveram como "trilha sonora" ao fundo durante todo o tempo em que permaneci na aldeia. Não havia rádios, televisões, aparelhos sonoros eletrônicos. Tudo feito ao vivo, com participação corporal eventual de todos da comunidade. O que mais me chamou a atenção foi a alegria e tranquilidade das crianças quase desnudas, brincando conjuntamente, fazendo pequenas expedições ao mato, tomando banho no riacho. Felicidade pura transparece em seus semblantes.

Um pouco antes de partir de retorno para Porto Alegre, ao final da 
tarde, fui conversar com José Cirilo e me despedir. Falei sobre o laudo antropológico que faria (e fiz depois), apontando elementos de ocupação tradicional daquele espaço. Fiz um rápido comentário sobre a alegria e tranquilidade das crianças, brincando juntas e sem a intervenção dos adultos por horas. Naquele momento, José Cirilo demonstrou profunda afetação e disse, numa voz abalada pela emoção, que fazia tempos que não presenciava isso, e que a alegria e liberdade das crianças é o melhor indício de que Nhanderú continua no comando. Ele afirmou de maneira categórica, com voz marcadamente engasgada pela emoção: "Nenhuma justiça e nenhuma polícia dos brancos vão poder enfrentar isso!".

\section{Referências bibliográficas}

ARNT, Mônica de Andrade. Mediações musicais e direitos autorais entre grupos Mbyá-Guarani no Rio Grande do Sul. Porto Alegre: PPGAS/UFRGS, 2010.

BERGAMASCHI, Maria Aparecida. Nhembo'e: Enquanto o encanto permanece! processos e práticas de escolarização nas aldeias Guarani. 2005. 273 f. Tese (Doutorado em Educação) - FACED, UFRGS, [2005].

BOURDIEU, P. A economia das trocas simbólicas. São Paulo: Perspectiva, 1987.

CADOGAN, L. Ayvu Rapyta: textos míticos de los Mbyá-Guaraní del Guairá. Revista de Antropologia, v. 1, n. 2, p. 123-132, 1953.

Ayvu Rapyta. Revista de Antropologia, v. 2, n. 1, p. 37-46, 1954.

Ayvu Rapyta: textos míticos de los Mbyá-guaraní del Guairá. Boletim 227Antropologia, São Paulo, n. 5, 1959.

CADOGAN, León; SHADEN, E. Ayvu Rapyta: textos míticos de los Mbyá-Guaraní del Guairá. Revista de Antropologia, v. 1, n. 1, p. 35-41, 1953.

CRAPANZANO, Vincent. Horizontes Imaginativos e o Aquém e o Além. Revista de. Antropologia, São Paulo, v. 48, n. 1, p. 363-384, 2005.

DESCOLA, Philippe. Societies of nature and the nature of society. In: KUPER, Adam (Org.). Conceptualizing society. Londres: Routledge, 1992. p. 107-126.

. Genealogia de objetos e antropologia da objetivação. Horizontes Antropológicos, Porto Alegre, v. 8, n. 18, p. 93-112, 2002. 
DUMONT, Louis. Homo Hierarchicus: o sistema das castas e suas implicações. São Paulo: EDUSP, 1997.

FAUSTO, Carlos. Inimigos Fiéis: História, Guerra e Xamanismo na Amazônia. São Paulo: EDUSP, 2001.

Se Deus fosse jaguar: canibalismo e cristianismo entre os Guarani (séculos XVIXX). Mana, Rio de Janeiro, v. 11, n. 2, p. 385-418, 2005.

FAVRET-SAADA, Jeanne. "Ser afetado". Cadernos de Campo, São Paulo, v. 14, p. 155-162, 2005.

FERNANDES, Florestan. A função social da guerra na sociedade tupinambá. São Paulo: Editora Globo, 2006.

HALL, Stuart. Da diaspora: identidades e mediações culturais. Belo Horizonte: Editora UFMG, 2003.

HANNERZ, Ulf. Fluxos, fronteiras, híbridos: palavras-chave da antropologia transnacional. Mana, Rio de Janeiro, v. 3, n. 1, p. 7-39, 1997.

HUSSERL, Edmund. Ideias Diretrizes para uma Fenomenologia. Paris: Gallimard, 1950.

INGOLD, Tim. Trazendo as coisas de volta à vida: emaranhados criativos num mundo de materiais. Horizontes Antropológicos, Porto Alegre, v. 18, n. 37, p. 25-44, 2012.

KUSCH, Rodolfo. Obras completas: tomo II. Córdoba: Editorial Fundación Ross, 2000.

LEROI-GOURHAN, Andre. O gesto e a palavra 2: memória e ritmos. Porto: Edições 70, 1987.

LÉVI-STRAUSS, Claude. Anthropologie structurale. Paris: Plon, 1974.

O Pensamento Selvagem. Campinas: Papirus, 1997.

MAUSS, Marcel. Les techniques du corps in Sociologie et Anthropologi. Paris: PUF, 1950.

Sociologia e antropologia. São Paulo: Cosac Naify, 2003.

MELIÁ, Bartomeu S.J. Una nación, dos culturas. Asunción: Imprenta Salesiana, 1988.

OLIVEIRA, Roberto C. O Mal Estar da Ética na Antropologia Prática. In: VÍCTORA, Ceres et al. (Org.) Antropologia e Ética: o debate atual no Brasil. Niterói: EdUFF, 2004. p. 21-32. 
OLIVEIRA, João Pacheco de. (Org.) Indigenismo e Territorialização: Poderes, Rotinas e Saberes Coloniais no Brasil Contemporâneo. Rio de Janeiro: Contra Capa, 1996.

PIRES, Daniele M. Alegorias etnográficas do Mbyá Rekó em cenários interétnicos no Rio Grande do Sul (2003-2007): discurso, prática e holismo Mbyá frente às políticas públicas diferenciadas. Porto Alegre: PPGAS/UFRGS, 2007.

RUSCHEL, Ruy Ruben. O direito de propriedade dos índios missioneiros. Veritas, Porto Alegre, v. 39, n. 153, p.103-116, 1994.

SAHLINS, Marshall. Ilhas de História. Rio de Janeiro: Jorge Zahar Edições, 1997.

SCHADEN, Egon. Aculturação indígena: ensaios sobre fatores e tendências da mudança cultural de tribos índias em contato com o mundo dos brancos. São Paulo, Pioneira, 1959. Católica, 1974.

El Guaraní conquistado e reducido. Asunción: CEADUC, Universidad Aspectos fundamentais da cultura Guarani. São Paulo: EPU/EDUSP, 1986.

TAUSSIG, Michael. Xamanismo, colonialismo e o homem selvagem: um estudo sobre o terror e a cura. Rio de Janeiro: Paz e Terra, 1993.

TURNER, Frederick. O espírito ocidental contra a natureza: mito, história e as terras selvagens. Rio de Janeiro: Campus, 1990.

VIVEIROS DE CASTRO, Eduardo. A fabricação do corpo na sociedade xinguana. Boletim do Museu Nacional, Série Antropologia, n. 32, p. 40-49, 1979.

Araweté: os deuses canibais. Rio de Janeiro: Jorge Zahar Ed., 1986.

2002.

A Inconstância da Alma Selvagem e outros ensaios. São Paulo: Cosac Naify,

WAGNER, Roy. A invenção da cultura. São Paulo: Cosac Naify, 2010

WRIGHT, Pablo. Ser-en-el-sueño: crónicas de historia y vida toba. Buenos Aires: Biblos, 2008.

Recebido em: 01/11/2017 * Aprovado em: 10/11/2017 * Publicado em: 31/12/2017 